\title{
Harga Saham (Studi Kausalitas Nilai Tukar Rupiah, Interest Rate, Inflasi, Dan Volume Perdagangan Saham) Pada Perusahaan Pertambangan Yang Terdaftar Di Bursa Efek Indonesia Tahun 2012-2016
}

\author{
Ai Elis Karlinda, Muhammad Fikri Ramadhan \\ Universitas Putra Indonesia YPTK Padang \\ aieliskarlinda@upiyptk.ac.id
}

\begin{abstract}
This study aims to determine the effect rupiah exchange rate, interest rate, inflation, and trading volume on the stock price mining company partially and simultaneously. The analytical method used is the method of multiple linear regression analysis and hypothesis testing with stock price monthly data, the rupiah exchange rate, the interest rate, the inflation, and the trading volume period in 2012-2016.

The results showed that : 1) the exchange rate of rupiah is partially no significant positive effect on stock prices. 2) the interest rate is partially no significant positive effect on stock price. 3) the Inflation is partially no significant positive effect on stock prices. 4) and the trading volume is partially a significant positive effect on stock prices. 5) While the exchange rate of Rupiah, interest rate, inflation, and trading volume simultaneously a significant positive effect on stock prices of mining companies period in 2012-2016.
\end{abstract}

Keywords: stock price, the rupiah exchange rate, interest rate, inflation, and trading volume.

\section{Pendahuluan}

Investasi sebagai suatu kegiatan yang menempatkan dana pada satu atau lebih dari satu asset selama periode tertentu dengan mengharapkan keuntungan dan peningkatan nilai investasi. Kegiatan berinvestasi di Pasar Modal merupakan salah satu kegiatan ekonomi yang banyak diminati oleh masyarakat yang mempunyai dana berlebih. Ketika melakukan investasi dalam bentuk saham seringkali yang tergolong mempunyai resiko tinggi, karena sifatnya yang peka terhadap perubahan yang terjadi oleh sumber yang berasal dari luar maupun dari dalam negeri. Perubahan tersebut dapat berdampak secara positif ataupun negative terhadap harga saham di Pasar Modal.

Investasi berupa saham pada pasar modal merupakan investasi yang sifatnya jangka pendek. Dapat dilihat dari tingkat pengemabalian (return) yang diukur dengan laba modal (capital gain). Bagi para spekulator yang menyukai laba modal, pasar modal bisa menjadi tempat yang menarik di mana para investor bisa membeli dan menjual kembali sahamnya. Membeli pada saat harga saham turun dan menjualnya kembali pada saaat harga saham naik, selanjutnya diliat dari selisih harga beli dengan harga jual itulah yang kemudian akan dihitung keuntungannya.

Persaingan ekonomi yang semakin ketat, membuat manajemen perusahaan berusaha untuk menampilkan kinerja terbaik dari perusahaan itu sendiri, agar tidak terjadinya kerugian, untuk itu baik buruknya kinerja perusahaan akan berpengaruh kepada nilai pasar dan juga akan berdampak kepada minat investor untuk menanamkan atau menarik investasinya dari 
perusahaan yang bersangkutan. Aktivitas perusahaan berkembang dimulai dari fungsi yang memfokuskan pada bagaimana cara untuk mendapatkan dana sampai kepada fungsi kemana dana itu digunakan. Perolehan dan pemanfaatan dana tersebut bertujuan untuk pencapaian laba perusahaan.

Dampak dari pertumbuhan perekonomian ini membuat suatu negara tidak hanya jadi perhatian perusahaan saja, tetapi juga para investor. Investor harus mempertimbangkan berbagai hal yang mempengaruhi nilai suatu harga saham agar dapat menghasilakan keputusan yang terdapat dalam melakukan investasi.

Perubahan harga saham yang diperdagangkan di Bursa Efek Indonesia dipengaruhi oleh perkembangan yang terjadi didalam indeks saham sektor pertambangan. Pada aktivitas pasar sekunder harga saham pertambangan mengalami fluktuasi baik berupa kenaikan maupun penurunan. Pembentukan harga saham dipengaruhi oleh permintaan dan penawaran investor atas saham tersebut. Naik turunnya permintaan dan penawaran tersebut terjadi karena adanya beberapa faktor, baik yang bersifat dari dalam maupun dari luar perusahaaan yaitu seperti (nilai tukar rupiah, interst rate, inflasi, dan volume perdagangan).

Tabel 1 : Pergerakan Harga Saham Pertambangan Sub Sektor Batubara tahun 2013-2014

\begin{tabular}{|c|r|r|c|r|r|}
\hline Month & Price & Change & Month & \multicolumn{1}{c|}{ Price } & \multicolumn{1}{c|}{ Change } \\
\hline Jan 2013 & 96.95 & $0.91 \%$ & Jan 2014 & 87.97 & $-1.64 \%$ \\
\hline Feb 2013 & 100.35 & $3.51 \%$ & Feb 2014 & 83.03 & $-5.62 \%$ \\
\hline Mar 2013 & 97.32 & $-3.02 \%$ & Mar 2014 & 79.75 & $-3.95 \%$ \\
\hline Apr 2013 & 93.23 & $-4.20 \%$ & Apr 2014 & 78.52 & $-1.54 \%$ \\
\hline May 2013 & 93.13 & $-0.11 \%$ & May 2014 & 78.83 & $0.39 \%$ \\
\hline Jun 2013 & 89.64 & $-3.75 \%$ & Jun 2014 & 77.35 & $-1.88 \%$ \\
\hline Jul 2013 & 82.22 & $-8.28 \%$ & Jul 2014 & 74.04 & $-4.28 \%$ \\
\hline Aug 2013 & 82.22 & $0.00 \%$ & Aug 2014 & 74.25 & $0.28 \%$ \\
\hline Sep 2013 & 83.30 & $1.31 \%$ & Sep 2014 & 71.53 & $-3.66 \%$ \\
\hline Oct 2013 & 85.44 & $2.57 \%$ & Oct 2014 & 68.98 & $-3.56 \%$ \\
\hline Nov 2013 & 88.36 & $3.42 \%$ & Nov 2014 & 67.33 & $-2.39 \%$ \\
\hline Dec 2013 & 89.44 & $1.22 \%$ & Dec 2014 & 67.16 & $-0.25 \%$ \\
\hline
\end{tabular}

Sumber : www.indexmundi.com

Dari tabel 1 di atas sudah sangat jelas bahwa harga saham perusahaan pertambangan sub sektor batubara mengalami fluktuatif dari tahun 2013 dapat kita lihat dari tabel harga saham pada bulan Januari dan Februari mengalami kenaikan dari 96.95 ke 100.35 sedangkan pada bulan Maret hingga bulan Agustus mengalami penurunan harga saham yaitu dari harga 97.32, 93.23, 93.13, 89.64, 82.22, 82.22 yang disebabkan oleh inflansi dan interest rate yang terjadi di Indonesia, namun pada bulan Oktober sampai bulan Desember mengalami kenaikan harga saham yaitu dari harga 88.36 ke harga 89.44. Dapat disimpulkan bahwa nilai harga saham tertinggi terjadi pada bulan Februari yaitu sebesar 100.35 sedangkan nilai harga saham terendah terjadi pada bulan Juli yaitu sebesar 82.22 .

Sedangkan untuk tahun 2014 dari bulan Januari sampai bulan Juli terjadi penurunan yang signifikan yaitu dari harga 87.97 sampai ke harga 74.04 dan terjadi kenaikan kembali pada bulan Agustus di harga 74.25 dan mengalami penurunan kembali pada bulan September sampai dengan bulan Desember dari harga 71.53 sampai harga 67.16. Dapat disimpulkan bahwa nilai tertinggi harga saham terjadi pada bulan Januari yaitu sebesar 87.97 dan nilai terendah terjadi pada bulan Desember yatitu sebesar 67.16, dengan demikian harga saham sub sektor batubara pada tahun 2014 mengalami penurunan dan kenaikan atau bisa desebut juga dengan berfluktuatif. 
Tabel 2 : Pergerakan Harga Saham Pertambangan Sub Sektor Batubara tahun 2015-2016

\begin{tabular}{|c|c|c|c|c|c|}
\hline Month & Price & Change & Month & Price & Change \\
\hline Jan 2015 & 64.72 & $-3.63 \%$ & Jan 2016 & 53.43 & $-4.37 \%$ \\
\hline Feb 2015 & 70.66 & $9.18 \%$ & Feb 2016 & 53.78 & $0.66 \%$ \\
\hline Mar 2015 & 68.34 & $-3.28 \%$ & Mar 2016 & 55.44 & $3.09 \%$ \\
\hline Apr 2015 & 61.20 & $-10.45 \%$ & Apr 2016 & 54.66 & $-1.41 \%$ \\
\hline May 2015 & 65.67 & $7.30 \%$ & May 2016 & 54.53 & $-0.24 \%$ \\
\hline Jun 2015 & 63.10 & $-3.91 \%$ & Jun 2016 & 56.23 & $3.12 \%$ \\
\hline Jul 2015 & 64.48 & $2.19 \%$ & Jul 2016 & 64.42 & $14.57 \%$ \\
\hline Aug 2015 & 63.39 & $-1.69 \%$ & Aug 2016 & 71.33 & $10.73 \%$ \\
\hline Sep 2015 & 61.77 & $-2.56 \%$ & Sep 2016 & 76.37 & $7.07 \%$ \\
\hline Oct 2015 & 57.33 & $-7.19 \%$ & Oct 2016 & 96.24 & $26.02 \%$ \\
\hline Nov 2015 & 55.78 & $-2.70 \%$ & Nov 2016 & 111.43 & $15.78 \%$ \\
\hline Dec 2015 & 55.87 & $0.16 \%$ & Dec 2016 & 93.13 & $-16.42 \%$ \\
\hline
\end{tabular}

Sumber : www.indexmundi.com

Dari tabel 2 sama halnya dengan tabel harga saham perusahaan pertambangan sub sektor batubara pada tahun 2012 sampai dengan tahun 2014. Kemudian, tabel di atas adalah lanjutannya dan sudah sangat jelas bahwa harga saham perusahaan pertambangan sub sektor batubara mengalami fluktuatif juga dari tahun 2015 dapat dilihat dari bulan Januari ke Februari terjadi kenaikan harga saham yaitu sebesar 64.72 ke harga 79.66, bulan Maret dan April harga saham mengalami penurunan yaitu dari harga 68.34 ke harga 61.20 , selanjutnya mengalami kenaikan di bulan Mei sebesar 65.67 setelah itu bulan Juni sampai dengan bulan Desember mengalami penurunan yaitu dari harga 63.10 ke harga 55.87. Dapat disimpulkan bahwa nilai tertinggi harga saham terjadi pada bulan Februari yaitu sebesar 70.66 dan nilai terendah terjadi pada bulan November yaitu sebesar 55.78.

Sedangkan untuk tahun 2016 terjadi kenaikan harga saham dari bulan Januari sampai bulan Maret dari harga 53.43 ke harga 55.44, pada bulan Maret sampai bulan Mei terjadi penurunan dari harga 55.44 ke harga 54.53 dan terjadi kenaikan di bulan Juni sampai bulan November yaitu sebesar 56.23 sampai dengan harga 111.43 sedangkan pada bulann Desember harga saham mengalami penurunan yaitu diharga 93.13. Dennga demikian harga saham sub sektor batubara pada tahun 2016 mengalami penurunan dan kenaikan atau bisa disebut juga dengan berfluktuatif.

Nilai tukar rupiah menurut [1] berpengaruh negative dan signifikan terhadap harga saham, sedangkan penelitian yang dilakukan oleh [2] nilai tukar rupiah memiliki pengaruh negative dan signifikan terhadap nilai harga saham. Suku bunga menurut [3] berpengaruh positif dan signifikan terhadap harga saham. Sedangkan menurut [4] suku bunga memiliki pengaruh yang negatifterhadaphargasaham. Inflasi menurut [5] dan [6] terdapat pengaruh yang signifikan terhadap harga saham. Sedangkan menurut [7] inflasi memiliki pengaruh tidak signifikan terhadap harga saham. Menurut [8] yang menghasilkan bahwa volume perdagangan berpengaruh positif dan signifikan terhadap harga saham. Berbanding terbalik dengan penelitian dari [9] di dalam penelitiannya menunjukkan hasil bahwa volume perdagangan berpengaruh negative dan signifikan.

\section{Metodologi Penelitian Objek Penelitian}

Yang menjadi objek penelitian adalah semua perusahaan pertambangan yang terdaftar di Bursa Efek Indonesia (BEI) pada periode 2012 sampai dengan tahun 2016. 


\section{Definisi Operasional Variabel}

Definisi operasional yang penulis gunakan dalam penyelesaian tugas akhir ini adalah:

1. Nilai Tukar Rupiah

Menurut [10] kurs adalah nilai tukar uang dengan mata uang lainnya, kurs atau nilai tukar biasanya digunakan dalam transaksi yang melibatkan dua negara atau lebih Kurs atau nilai tukar rupiah merupakan satu indicator ekonomi makro yang terkait dengan besaran APBN.

Rumus :

$$
\text { KursTengah }=\frac{\text { KurS Jual }+ \text { Kurs Beli }}{2}
$$

\section{Interest Rate}

Menurut [11] suku bunga merupakan balas jasa yang diberikan oleh bank yang berdasarkan prinsip konvensional kepada nasabah yang membeli atau menjual produknya.

Rumus :

$$
\mathrm{SBI}=\frac{\text { Jumlah tingkat suku bunga periode harian selama } 1 \text { bulan }}{\text { jumlah periode waktu selama } 1 \text { bulan }}
$$

3. Inflasi

Menurut [12] inflasi adalah suatu kondisi atau keadaan terjadinya kenaikan harga untuk semua barang secara terus menerus yang berlaku pada suatu perekonomian tertentu.

Rumus :

$$
\operatorname{In} f(t)=\frac{I H K(t)-I H K(t-1)}{I H K(t-1)} x 100 \%
$$

4. Volume Perdagangan

Volume perdagangan saham menurut [13] merupakan aspek dinamis dari pasar yang menggambarkan permintaan dan penawaran dari perilaku pasar. Volume dapat menjadi kunci untuk memahami apa yang sedang terjadi di perdagangan saham.

Rumus:

$$
\text { Volume }=\text { Jumlah volume perdagangan saham satu periode }
$$

5. Harga Saham

Menurut [14] harga saham adalah uang yang dikeluarkan untuk memperoleh bukti penyertaan atau pemilikan suatu perusahaan.

Rumus :

$$
\text { Harga Saham }(t)=\frac{P(t)-P(t-1)}{P(t-1)} X 100 \%
$$




\section{Populasi dan Sampel Populasi}

Menurut [15] populasi adalah wilayah generalisasi yang terdiri atas objek atau subjek yang mempunyai kualitas dan karakteristik tetentu yang ditetapkan oleh peneliti untuk dipelajari dan kemudian ditarik kesimpulannya. Dalam penelitian ini yang menjadi populasi adalah 42 perusahaan pertambangan yang terdaftar di BEI 2012-2016.

\section{Sampel}

Menurut [15] Sampel adalah bagian dari jumlah dan karakteristik yang dimiliki oleh populasi tersebut. Dalam pengambilan sampel dilakukan dengan Purposive Sampling yaitu pengambilan criteria sampel sesuai dengan penelitian yang akan dilakukan. Sampel dalam penelitian ini sebanyak 6 perusahaan.

\section{Analisis Regresi Berganda}

Menurut [16] Regresi linear berganda pada dasarnya merupakan perluasan dari regresi linear sederhana, yaitu menambah jumlah variabel bebas yang sebelumnya hanya satu menjadi dua atau lebih variabel bebas. Persamaan regresi linier berganda sebagai berikut:

$$
\text { Rumus : } \mathbf{Y}=\mathbf{a}+\mathbf{b}_{1} \mathbf{X}_{1}+\mathbf{b}_{2} \mathbf{X}_{2}+\mathbf{b}_{3} \mathbf{X}_{3}+\mathbf{b}_{4} \mathbf{X}_{4}+\mathbf{e}
$$

Dimana:

$$
\begin{aligned}
& \mathrm{X} 1=\text { Nilai Tukar Rupiah } \\
& \mathrm{X} 2=\text { Interest Rate } \\
& \mathrm{X} 3 \quad=\text { Inflasi } \\
& \mathrm{X} 4 \quad=\text { Volume Perdagangan } \\
& \mathrm{Y} \quad=\text { HargaSaham } \\
& \mathrm{a}=\text { Konstanta } \\
& b_{1}, b_{2}, b_{3}, b_{4}=\text { Koefisien regresi masing-masing variabel } \\
& \mathrm{e}=\text { Standar error }
\end{aligned}
$$

\begin{tabular}{|c|c|c|c|c|c|c|}
\hline \multicolumn{7}{|c|}{ Coefficients $^{\mathrm{a}}$} \\
\hline \multirow{2}{*}{\multicolumn{2}{|c|}{ Model }} & \multicolumn{2}{|c|}{$\begin{array}{l}\text { Unstandardized } \\
\text { Coefficients }\end{array}$} & \multirow{2}{*}{$\begin{array}{c}\text { Standardized } \\
\text { Coefficients } \\
\text { Beta }\end{array}$} & \multirow[b]{2}{*}{$\mathrm{T}$} & \multirow[b]{2}{*}{ Sig. } \\
\hline & & B & $\begin{array}{l}\text { Std. } \\
\text { Error }\end{array}$ & & & \\
\hline 1 & (Constant) & 5742,423 & 424,252 & & 13,535 &, 000 \\
\hline & $\begin{array}{l}\text { Nilai_Tukar_Rupi } \\
\text { ah }\end{array}$ &,- 300 & ,045 &,- 695 & $-6,609$ & ,000 \\
\hline & Interest_Rate & $-73,038$ & 99,678 &,- 078 &,- 733 & ,467 \\
\hline
\end{tabular}

\section{Hasil dan Pembahasan}

\section{Analisis Regresi Linear Berganda}

Analisis regresi ini digunakan untuk melihat pengaruh variabel bebas yaitu: Nilai Tukar Rupiah (X1), Interest rate (X2), Inflasi (X3), Volume Perdagangan (X4), secara simultan terhadap variable terikat : Harga Saham(Y) dengan asumsi variabel bebas lain dianggap konstan.

Table 3 : Regresi Linear Berganda Variabel Nilai Tukar Rupiah, Interest rate, Inflasi, dan Volume Perdagangan Terhadap Harga Saham 


\begin{tabular}{|c|c|c|c|c|c|}
\hline Inflasi & $-56,733$ & 29,265 &,- 140 & $-1,939$ & ,058 \\
\hline $\begin{array}{l}\text { Volume_Perdagan } \\
\text { ga }\end{array}$ & 2,633 & ,000 & ,214 & 3,126 & ,003 \\
\hline
\end{tabular}

Dilihat dari tabel 3 di atas maka diperoleh persamaan regresinya yaitu :

$$
Y=5742,423-0,300 X_{1}-73,038 X_{2}-56,733 X_{3}+2,633 X_{4}+e
$$

\section{Uji Hipotesis}

\section{Uji Hipotesis Secara Parsial (Uji t)}

Uji t digunakan untuk menguji hipotesis secara pasrsial atau individual masing-masing variabel $(\mathrm{X})$ terhadap Variabel $(\mathrm{Y})$. Dimana pengujian ini membandingkan antara nilai probabilitas signifikan dengan tingkat signifikan (alpha) 0,05 dengan derajat kebebasan (df) n-k-1 yaitu 60-4-1=55 ( $\mathrm{n}$ adalah jumlah data dan $\mathrm{k}$ adalah jumlah variabel bebas) kemudian didapatkan hasil untuk ttabel sebesar 2,004.

Tabel 4 : Pengujian Secara Parsial Atas Semua Variabel Independen

Coefficientsa

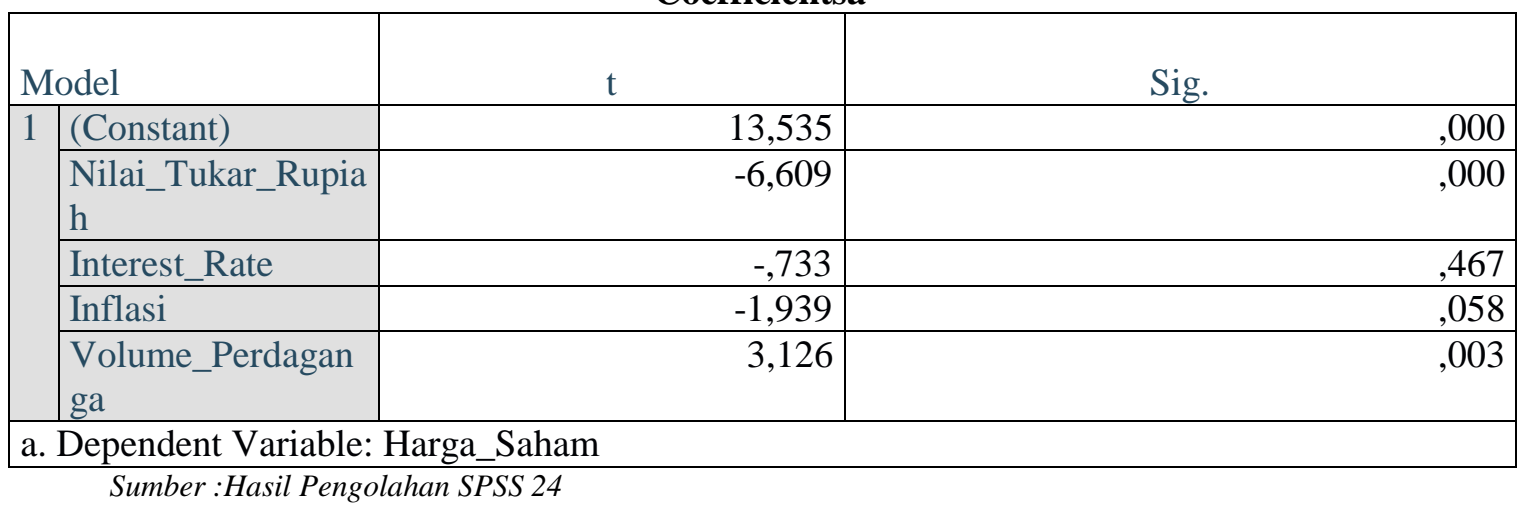

Berdasarkan tabel 4 di atas maka dapat disimpulkan sebagai berikut :

Pengaruh Nilai Tukar Rupiah terhadap Harga Saham

Dari tabel 4 diatas di ketahui t hitung $>\mathrm{t}$ tabel $(-6,609<2,004)$ dengan tingkat siginifikan $(0,000<0,05)$, artinya secara parsial terdapat pengaruh negatif signifikan antara nilai tukar rupiah dengan harga saham.

\section{Pengaruh Interest Rate terhadap Harga Saham}

Dari tabel 4 diatas di ketahui $\mathrm{t}$ hitung $<\mathrm{t}$ tabel-0,733<2,004) dengan tingkat siginifikan $(0,467>0,05)$, artinya secara parsial tidak terdapat pengaruh negatif tidak signifikan antara interest rate dengan harga saham.

\section{Pengaruh Inflasi terhadap Harga Saham}

Dari tabel 4 diatas di ketahui $\mathrm{t}$ hitung $<\mathrm{t}$ tabel-1,939<2,004) dengan tingkat siginifikan $(0,058>0,05)$, artinya secara parsial terdapat pengaruh negative tidak signifikan antarain flasi dengan harga saham. 


\section{Pengaruh Volume Perdagangan terhadap Harga Saham}

Dari tabel 4 diatas di ketahui t hitung $>\mathrm{t}$ tabel $(3,126>2,004)$ dengan tingkat siginifikan $(0,003<0,05)$, artinya secara parsial terdapat pengaruh positif signifikan antara volume pergadangan dengan harga saham.

\section{Uji Hipotesa Secara Simultan (Uji F)}

Didalam Uji F digunakan tingkat signifikan 0,05 (uji 2 sisi) untuk nilai Ftabel menggunakan tingkat keyakinan 95\%, alpha 5\% (jumlah variabel-1) atau 3-1=2 (n-k1) atau 60-4-1=55, maka hasil untuk Ftabel adalah 2,539.

Tabel5 :Uji Hipotesis Secara Simultan

\begin{tabular}{|c|c|c|c|c|c|c|}
\hline \multicolumn{7}{|c|}{ ANOVA $^{a}$} \\
\hline \multicolumn{2}{|c|}{ Model } & Sum of Squares & Df & Mean Square & F & Sig. \\
\hline \multirow[t]{3}{*}{1} & Regression & 26199808,600 & 4 & 6549952,151 & 88,563 &, $000^{\mathrm{b}}$ \\
\hline & Residual & 4067684,997 & 55 & 73957,909 & & \\
\hline & Total & 30267493,600 & 59 & & & \\
\hline \multicolumn{7}{|c|}{ a. Dependent Variable: Harga_Saham } \\
\hline & $\begin{array}{l}\text { lictors: }(\mathrm{Cr} \\
\text { t_Rate }\end{array}$ & t), Volume_Pe & $\overline{\text { ngan, } 1}$ & , Nilai_Tukar_R & & \\
\hline
\end{tabular}

Dilihat dari tabel 5 di atas didapatkan tingkat signifikan yaitu $0,000<0,05$ yang mana angka ini menunjukkan $\mathrm{F}_{\text {hitung }} 88,563>\mathrm{F}_{\text {tabel }}$ 2,539 maka penulis berkesimpulan nilai tukar rupiah $\left(\mathrm{X}_{1}\right)$, interest rate $\left(\mathrm{X}_{2}\right)$, inflasi $\left(\mathrm{X}_{3}\right)$ dan volume perdagangan $\left(\mathrm{X}_{4}\right)$ mempunyai pengaruh yang positif signifikan dengan harga saham(Y).

\section{Koefisien Derteminasi}

Tabel6 :Hasil Uji Koefisien Derteminasi $\left(\mathbf{R}^{2}\right)$

\begin{tabular}{|c|c|c|c|c|}
\hline \multicolumn{5}{|c|}{ Model Summary $^{b}$} \\
\hline Model & $\mathrm{R}$ & R Square & Adjusted R Square & Std. Error of the Estimate \\
\hline 1 &, $930^{\mathrm{a}}$ & 866 & 856 & 271,95203 \\
\hline
\end{tabular}

a. Predictors: (Constant), Volume_Perdaganga, Inflasi, Nilai_Tukar_Rupiah, Interest_Rate

b. Dependent Variable: Harga_Saham

Sumber :HasilPengolahan SPSS 24

Daritabel 6 di atas diperoleh angka Adjusted Rsquare sebesar 0,856 atau 85,6\%, ini menunjukkan bahwa persentase sumbangan variable independen $(\mathrm{X})$ terhadap variabel dependen (Y) sebesar 0,856 atau 85,6\%. Sedangkan sisanya sebesar 14,4\% dipengaruhi oleh variabel lain yang tidak dibahas didalam penelitian ini.

\section{Kesimpulan}

Kesimpulan dalam penelitian ini adalah:

1. Tidak terdapat pengaruh yang positif signifikan antara nilai tukar rupiah terhadap harga saham. Hal ini terjadi jika kondisi nilai tukar Rupiah diperkirakan buruk, maka kemungkinan besar refleksi pada indeks harga saham yang akan menurun. Hal ini karena pelemahan kurs Rupiah terhadap mata uang asing merupakan sinyal negatif bagi investor sehingga akan mempengaruhi harga saham tersebut. 
2. Tidak terdapat pengaruh yang positif signifikan antara interest rate terhadap harga saham. Hal ini terjadi apabila pada saat tingkat suku bunga tinggi, dapat mempengaruhi para investor untuk menyimpan dana yang dimiliki dalam bentuk Sertifikat Bank Indonesia karena imbal hasil yang tinggi dengan tingkat risiko yang rendah. Sebaliknya pada saat suku bunga rendah, hal ini dapat mempengaruhi para investor untuk menginvestasikan dana yang dimiliki dalam bentuk saham yang memberikan imbal hasil yang lebih tinggi meskipun dengan tingkat risiko yang tinggi pula.

3. Tidak terdapat pengaruh yang positif signifikan antara inflasi terhadap harga saham. Hal ini terjadi apabila inflasi mengalami peningkatan merupakan sinyal negatif bagi para investor di pasar modal, karena inflasi meningkatkan pendapatan dan biaya perusahaan. Jika peningkatan biaya produksi lebih tinggi daripada peningkatan harga produk, maka profitabilitas perusahaan akan turun.

4. Terdapat pengaruh yang positif signifikan antara volume perdagangan terhadap harga saham. Hal ini terjadi karena volume perdagangan menggambarkan banyaknya jumlah penawaran saham dan permintaan saham di pasar. Ilmu ekonomi menyatakan bahwa harga ditentukan oleh interaksi permintaan dan penawaran. Pada prinsipnya, analis teknikal sependapat dengan pernyataan ilmu ekonomi di atas. Volume perdagangan merupakan hal yang penting bagi investor karena menggambarkan tingkat likuiditas suatu saham. Semakin besar volume transaksi, maka semakin cepat dan semakin mudah sebuah saham diperjualbelikan, sehingga transformasi saham menjadi kas semakin cepat pula.

5. Terdapat pengaruh yang positif signifkan antara nilai tukar rupiah, interest rate, inflasi dan volume perdagangan secara bersama-sama terhadap harga saham. Hal ini terjadi karena naik turunnya harga saham bisa terjadi karena didalam perekonomian ada kekuatan tertentu yang menyebabkan ada kekuatan tertentu yang menyebabkan tingkat harga saham melonjak sekaligus, tetapi ada kekuatan lain yang menyebabkan kenaikan tingkat harga saham berlangsung terus menerus secara perlahan. Ini disebakan oleh adanya pengaruh dari fakor makro ekonomi seperti nilai tukar rupiah, interest rate dan inflansi, selain itu juga di pengaruhi oleh faktor mikro ekonomi salah satunya yaitu volume perdagangan saham.

\section{Daftar Pustaka}

[1] F. P. P. Kusuma, "Analisis Pengaruh Inflasi, Suku Bunga BI Rate dan Nilai Tukar Rupiah Terhadap Harga Saham (Studi Empiris Pada Perusahaan Sektor Pertambangan di BEI 20112013)," J. Manaj. Ekon. dan Bisinis, 2015.

[2] R. Kurniadi, "Analisis Pengaruh Nilai Tukar, Suku Bunga (Sbi)Dan Jumlah Uang Beredar (Jub), Terhadap Nilaiharga Saham Sektor Propertidi Bursa Efek Indonesia (BEI)(Periode 2006-2011)," Ilmu Ekon. dan Stud. Pembang., 2013.

[3] F. P. P. Kusuma, "Analisis Pengaruh Inflasi, Suku Bunga BI Rate dan Nilai Tukar Rupiah Terhadap Harga Saham (Studi Empiris Pada Perusahaan Sektor Pertambangan di BEI 20112013)," Skripsi Thesis, Univ. Muhammadiyah Surakarta, 2015.

[4] A. Rianti, "Pengaruh ROE, EPS, Tingkat Bunga SBI, Tingkat Inflasi dan Nilai Tukar Rupiah Terhadap Harga Saham di Bursa Efek Indonesia," Perbanas Rev., vol. vo. 1 No., 2015.

[5] F. S. Suryadie, "Pengaruh Tingkat Inflasi, Nilai Tukar Rupiah, Suku Bunga, Return On Equity (Roe) Dan Return On Asset (Roa) Terhadap Harga Saham (Studi pada Perusahaan BUMN sektor konstruksi Go Publicdi BEI 2012-2016)," Univ. Pas., 2017.

[6] T. dan S. S. Ginting Maria Ratna, "Pengaruh Tingkat Suku Bunga, Nilai Tukar dan Inflasi 
Terhadap Harga Saham (Studi pada Sub Sektor Perbankan Di Bursa Efek Indonesia Periode 2011-2015)," Adm. Bisnis, vol. Vol. 35 No, 2016.

[7] A. I. Fachrial, "Pengaruh Kinerja Keuangan, Inflasi, Dan Nilai Tukar Terhadap Harga Saham Pada Perusahaan Rokok,” J. Ilmu dan Ris. Manaj., vol. Vol.5 No., 2016.

[8] S. Wiedya Tri, "Analisis Pengaruh Volume Perdagangan, Frekuensi Perdagangan, Dan Order Imbalanceterhadap Volatilitas Harga Saham Pada Perusahaan Go Publicdi Bursa Efek Indonesia," Manaj. Fak. Ekon., 2016.

[9] U. D. T. Putri, “Analisis Pengaruh Volume Perdagangan, Cr, Der, Roa, Dan Tato Terhadap Harga Saham(StudiPada Perusahaan Manufaktur Go Public Sektor Food dan Beverages Yang Terdaftar Di BEI Tahun 2011-2014),” Ekon. dan bisnis Univ. Dipenogoro Semarang, 2016.

[10] M. Ekananda, Analisis Ekonometrika Data Panel Edisi 2, Teori Lengkap dan Pembahasan Menyeluruh, Bagi Penelitian Ekonomi, Bisnis dan Sosial, Edisi 2. Jakarta: Mitra Wacana Media, 2018.

[11] Kasmir, Analisis Laporan Keungan. Jakarta: Rajawali Per, 2018.

[12] S. Karya, Detri dan Syamsuddin, Makro Ekonomi : Pengantar Untuk Manajemen. Jakarta: Raja Grafindo Persada, 2016.

[13] S. Muhyi Abdul Herwan Dan, "Analisis Perbandingan Volume Perdagangan Saham Sebelum dan Sesudah Stock Split Di Bursa Efek Indonesia," ilmu Polit. dan Komun., vol. Vol VIII N, 2017.

[14] P. Anoraga, Manajemen Bisnis. Semarang: Rieneka Cipta, 2013.

[15] Sugiyono, Metode Penelitian Pendidikan Pendekatan Kuantitatif, Kualitatif dan R\&D - Sugiyono. Bandung: Alfabeta, 2019.

[16] A. Sanusi, Metode Penelitian Bisnis, disertai contoh proposal penelitian bidang ilmu ekonomi dan manajemen. Jakarta: Salemba Empat, 2014. 